\title{
A viral grandfather: genomics in 2010 contradict Darwin's vision of evolution
}

\author{
D. Raoult
}

Received: 16 December 2010 /Accepted: 23 December 2010/Published online: 27 May 2011

(C) Springer-Verlag 2011

The genomic discoveries of the year 2010 question linear vision, without leaps of Darwin's evolution scheme [1,2]. Indeed, despite its conflict with creationists [3], the theory of evolution of Darwin was paradoxically very deeply impregnated by a biblical vision of the world with, in particular, the rejection of de novo creation or massive species recombination. As a matter of fact, Darwin's theory is very compatible with the intelligent design theory. In addition, representation of its vision, illustrated by a tree, makes necessary the existence of one common ancestor at the origin of each branch which is a direct resurgence of the Adam and Eve creation theory [2]. This theory is impregnated with much of our accidental vision of the evolution of humans and other living beings, seriously questioned by the genomic discoveries of the year 2010. In microbiology, the evidence, based on genomic studies, of wide occurrences of lateral gene transfer, generate a very different model of evolution than in visible beings. It makes the tree figure unreliable [4].

Our vision of only one couple at the origin of the humans led us to think that Homo sapiens and Homo neanderthalensis did not mix together. This year, genetic studies showed that, on the contrary, in Eurasia, we had some Neanderthals in a significant proportion amongst our male ancestors [5]. The reason for which this is not found among our female ancestors (to which the mitochondria testify) [5] is not understood and may be related to differences of tolerance in interbreeding between the female Homo

D. Raoult $(\square)$

Faculté de Médecine, URMITE, UMR CNRS 6236, IRD 198,

Université de la Méditerranée,

13005 Marseille, France

e-mail: didier.raoult@gmail.com sapiens and the female Homo neanderthalensis. Moreover, recent work shows the existence of a cohabitation with a third group of man (Homo floresiensis) 20,000 years ago [6]. Finally, another study reveals the existence of a Homo-like Australopithecus (Australopithecus sediba) contradicting the theory separating Australopithecus and Homo sapiens [7]. This confirms that the speculation on the origins of Adam and Eve is not reasonable. Finally, the HHV6 virus has been found to commonly integrate human genomes and can be transmitted, evidencing our continuously changing mosaic nature [8]. In fact, in 2010, we found that some children have a virus, as did one of their forefathers.

Finally, human beings are complex ecosystems comprising more bacteria and viruses than eukaryotic cells on their mucosa and especially in the gut. Even human cells have many eukaryotic genes but also genes of bacterial origin (such as in mitochondria), genes of viral origin (more than $7 \%$ of our genome is issued from retroviruses) and of Archaea origin [9]. Currently, the most coherent model of evolution of living beings is the existence of large re-combinations, with the creation of chimerical species complexes abruptly reduced by external phenomena (probably related to stochastic phenomena) and geographical isolation, creating bottlenecks eliminating most of the organisms and selecting the future species. Therefore, current species may have been more commonly selected at random, rather than on a specific fitness.

On the whole, the Western vision of evolution is directly inspired from the bible. It does not admit the creation de novo of species as did Jacob, or genes, or the creation of chimerical species [10]. Metagenomic and genomic data, in contrast, found that a very significant proportion of genes found in living organisms or in the environment are ORFans, i.e. very unique genes, probably resulting from de novo creation, of which very few will be perpetuated. In 
fact, the evolution of living organisms resembles a rhizome rather than a tree [2]. This may apply to humans as well. The emergence of novel modes of thought, based on other religious briefs, will probably generate a radically different vision of evolution, thanks to the presence of more Indian and Chinese researchers with other beliefs.

\section{References}

1. Darwin C (1859) The origin of species. Harvard College Library, New York

2. Raoult D (2010) The post-Darwinist rhizome of life. Lancet 375:104-105

3. Raoult D (2008) Creationism - remember the principle of falsifiability. Lancet 372:2095-2096

4. Doolittle WF (1999) Phylogenetic classification and the universal tree. Science 284:2124-2129
5. Burbano HA, Hodges E, Green RE, Briggs AW, Krause J, Meyer M, Good JM, Maricic T, Johnson PL, Xuan Z, Rooks M, Bhattacharjee A, Brizuela L, Albert FW, de la Rasilla M, Fortea J, Rosas A, Lachmann M, Hannon GJ, Pääbo S (2010) Targeted investigation of the Neandertal genome by array-based sequence capture. Science 328:723-725

6. Krause J, Fu Q, Good JM, Viola B, Shunkov MV, Derevianko AP, Pääbo S (2010) The complete mitochondrial DNA genome of an unknown hominin from southern Siberia. Nature 464:894-897

7. Berger LR, de Ruiter DJ, Churchill SE, Schmid P, Carlson KJ, Dirks PH, Kibii JM (2010) Australopithecus sediba: a new species of Homo-like australopith from South Africa. Science 328:195204

8. Arbuckle JH, Medveczky MM, Luka J, Hadley SH, Luegmayr A, Ablashi D, Lund TC, Tolar J, De Meirleir K, Montoya JG, Komaroff AL, Ambros PF, Medveczky PG (2010) The latent human herpesvirus-6A genome specifically integrates in telomeres of human chromosomes in vivo and in vitro. Proc Natl Acad Sci USA 107:5563-5568

9. Raoult D (2010) Dépasser Darwin. Plon, France

10. Jacob F (1977) Evolution and tinkering. Science 196:1161-1166 